\title{
Corporate Governance and Executive Perquisites
}

\author{
Angela Andrews ${ }^{a}$, Scott C. Linn ${ }^{b^{*}}$, Han Yi $^{\mathrm{c}}$ \\ ${ }^{a}$ Kelley School of Business, Indiana University, Indianapolis, IN 46202, USA \\ ${ }^{\mathrm{b}}$ Michael F. Price College of Business, University of Oklahoma, Norman, OK 73019, USA \\ ${ }^{\mathrm{C}}$ School of Business Administration, Korea University, Seoul, Korea
}

\begin{abstract}
This study presents evidence on the relations between executive perquisite consumption and indicators of corporate governance, taking into account firm characteristics which may give rise to agency problems. Agency theory predicts that managers who own partial or no stakes in the firms they manage may be prone to excessive consumption of perquisites. We find that firms with weak corporate governance are more likely to award perquisites to executives. We also find that greater competitive pressures from real markets are associated with lower perquisite consumption. Firms characterized as being more prone to the presence of agency problems are associated with greater levels of perquisite consumption. Finally, there is evidence that not all perquisite consumption can be attributed to an agency problem. Efficiently operating firms are associated with greater levels of perquisite consumption as are larger firms. These results are consistent with the thesis that firms with a large asset base recruit and compensate high marginal product managers at a level consistent with the value they add. Our tests include an examination of the dollar value of perquisites consumed, the number of perquisites consumed and the types of perquisites consumed.
\end{abstract}

JEL: G34, M52

Keywords: Perquisites (“Perks”), Agency Costs, Corporate Governance, Executive Compensation

* Corresponding author. Tel.: +1 405325 3444; fax: +1 4053257688.

E-mail addresses: abandrew@indiana.edu (A. Andrews), slinn@ou.edu (S.C. Linn), han.yi@korea.ac.kr (H. Yi).

We thank Salim Chahine and participants at the Conference on Managerial Compensation, 2010, Cardiff University, as well as workshop participants at the University of Oklahoma, the University of Texas at Dallas, and the AAA FARS 2009 Midyear Meeting for comments on earlier drafts of the paper. Thanks also to Sarah McVay and Peter Demerjian for providing us their Data Envelopment Analysis data for the managerial ability measure. We also thank Kenneth Bills, Aman Kapoor, Spencer King and Yan Sun for research assistance.

This is the author's manuscript of the article published in final edited form as:

Angela Andrews, Scott Linn, \& Han Yi. (2017). Corporate governance and executive perquisites. Review of Accounting and Finance, 16(1), 


\section{Corporate Governance and Executive Perquisites}

\section{INTRODUCTION}

The expropriation of corporate resources by those who control a corporation, the selfdealing problem, has long been a topic of interest amongst observers concerned with the intersection of corporate practices and corporate governance (Jensen and Meckling, 1976; Shleifer and Vishny, 1997; Holmstrom and Kaplan, 2001, 2003; among others). The media is rife with stories of these corporate excesses. Jay Hooley, the CEO at State Street Corporation, had a car and driver at his disposal, the amount of this perquisite totaled $\$ 27,852$ (Healy 2013). Compared to Mr. Hooley's total compensation of $\$ 15.6$ million, this perquisite is miniscule but researchers view this type of perquisite consumption as executive excess. A contrasting view is that perquisites are simply one element of an optimally designed compensation package (Fama, 1980; Fama and Jensen, 1983; Murphy, 1999; Murphy, 2002; Core et al., 2003; among others).

In this study, we examine a unique set of data on perquisite consumption at 608 U.S. companies, between December 15, 2006 and June 30, 2007, which immediately followed the rule change implemented by the U.S. Securities and Exchange Commission (SEC) that increased the level of disclosure surrounding perquisites provided to executives. We chose the period immediately after the rule change in order to mitigate the number of firms that would react to the rule change by restructuring or eliminating their perquisite programs. The enhanced disclosure provides a glimpse into a facet of executive compensation that was once opaque, allowing us to determine whether the executive excess or managerial productivity explanations dominate perquisite consumption under greater disclosure rules. We examine: (1) the dollar amount of perquisites, (2) the number of perquisites, and (3) the specific types of perquisites awarded to the CEO and of the top five most highly compensated executives for the companies in our sample. 
We find that firms with weak corporate governance and less managerial ownership are more likely to award a higher dollar amount and number of perquisites to executives. Our evidence also shows that firms facing less product market competition also award larger perquisites to their executives, a finding consistent with the proposition that a lack of real market competition may increase the probability of abusive practices. Among the various types of perquisites, we find: air and long distance travel; equity related perquisites (not included in stock options or other equity compensation); legal, financial, and tax services; and, financial perquisites unrelated to savings or retirement, are more likely to be consumed by executives of firms characterized by weak governance. We also find evidence that perquisites may be rewards for productivity, which suggests a dual role for perquisite awards.

Our study is motivated in part by two important studies that examine the motives underlying perquisite consumption. Yermack (2006) presents evidence that firms disclosing the private use of corporate jets during the period 1993-2002 experience negative market revaluations. Yermack also finds the common stocks of those same firms tend to underperform subsequent to the disclosure compared to matching firms with no private jet use. Rajan and Wulf (2006), on the other hand, in a study of 300 firms sampled from the years 1986 to 1999 conclude that executives tend to use corporate jets in a fashion consistent with enhancing "productivity," not executive excesses. Prior to the new SEC disclosure requirement, perquisite awards were buried in the "all other compensation” category. The statutory change allows us to delve into a more comprehensive menu of perquisite award, specifically on both individual components and total perquisite consumption. We accomplish this by focusing on the number, type and amount of executive perquisites and how they vary by executive type. We are one of the first studies to take advantage of the depth and breadth of expanded disclosure provided by the change in financial reporting rules. 
As a consequence we are able to use the expanded disclosures to provide further evidence on the motivations behind the awarding of perquisites as additional compensation.

We also expand the literature on perquisite consumption by presenting evidence on whether product market competition motivates corporate actions. Karuna (2007) provided evidence that three dimensions of product market competition: price-cost margin, market size and entry costs influence management incentives. Our paper adds to the literature by addressing whether product market competition serves as a disciplining mechanism in another management context, the awarding and consumption of perquisites.

The remainder of the paper is organized as follows. We begin with a discussion of extant hypotheses regarding the determinants of perquisite consumption and the explanatory variables we use in our investigation in Section II. Section III describes the sample selection procedure and presents descriptive statistics. Section IV presents our empirical findings and Section V concludes.

\section{POTENTIAL DETERMINANTS OF PERQUISITE CONSUMPTION}

\section{Agency Problems, Corporate Governance and Perquisite Consumption}

A manager with a fractional equity stake in a firm does not bear the full cost of his perquisite consumption but reaps the full benefits. Perquisite consumption may therefore be a form of self-dealing, and may be indicative of the severity of vertical agency problems (Jensen and Meckling, 1976). ${ }^{1}$ If perquisite consumption is a product of agency problems, internal and external factors that may act to reduce excessive perquisite consumption include those features of the corporate governance system which incentivize and discipline managers. Internal governance measures include: 1) shareholder voting privileges, 2) various takeover defense provisions, 3)

\footnotetext{
${ }^{1}$ Yermack (2006) suggests a spillover effect may also emerge when perquisites result in no added real managerial productivity. He suggests that excess perquisites may foster low morale if employees believe management is taking advantage of perquisite consumption for personal gain and hence may result in a reduction in productivity overall.
} 
factors related to the election and organization of the board and 4) alignment of executive and shareholder interests via shareholdings. External governance pressures include: 1) the markets in which a firm buys and sells (e.g. the level of competition faced by the firm), 2) the institutional and concentrated shareholder pressure, and 3) the market for corporate control. ${ }^{2}$

We first examine internal governance mechanisms. First, we examine the corporate governance/shareholder rights index proposed by Gompers et al. (2003), which is an aggregation of factors characterizing corporate governance and shareholder rights, labeled as the GIM index. ${ }^{3}$ Specifically, the index includes characteristics that Gompers et al. (2003) group as follows: Delay factors, Voting factors, Protection factors, Other takeover defenses, and State of Incorporation factors. Larger values of the index are indicative of fewer overall shareholder rights, i.e. weaker governance. If corporate governance is an important determinant of perquisite consumption, then we expect to observe more perquisite consumption when governance is weak, and hence expect a positive relation between GIM and perquisite consumption.

A complementary indicator of governance not accounted for in the GIM index is the independence of the board of directors. ${ }^{4}$ Gillan (2006) refers to the board of directors as "..the lynchpin of corporate governance” (p. 385). The primary thesis as it would apply in the context of perquisites is that less independent boards of directors, those that are more likely to be controlled by the CEO, are more prone to allow managers to waste assets. This hypothesis predicts board

\footnotetext{
${ }^{2}$ Shleifer and Vishny (1997), Holmstrom and Kaplan (2001, 2003), Becht et al. (2003), Hermalin (2005), Gillan (2006), Djankov et al. (2008).

${ }^{3}$ The GIM index is a composite of twenty-four provisions in five sub-categories that a company may possess that limit shareholder rights and increase managerial power. The higher the score the greater the power management possesses. Basic data come from the corporate governance data files of RiskMetrics, ISS Governance Services, via WRDS.

${ }^{4}$ Bhagat and Bolton (2008) recently argued that accounting for a governance index, along with other governance characteristics not reflected in the index, leads to improved explanatory power in a model of company performance.
} 
independence to be inversely related to perquisite consumption. We measure board independence as the ratio of independent (outside) board members to total directors. ${ }^{5}$ We obtain these data from the RiskMetrics governance files as well as the proxy statements of the sample companies.

The third variable related to internal governance mechanisms is managerial ownership. McConnell and Servaes (1990) find that as the proportion of shares owned by managers increases so does the value of the firm. However, consistent with Morck et al. (1988), McConnell and Servaes (1990) find that inside equity ownership is non-linear and that as managerial ownership becomes highly concentrated firm value declines. Our proxy for the alignment of executive and shareholder interests via shareholdings (for instance, Ross, 1973, Jensen and Meckling, 1976) is the effective percentage of total shares held or controlled by the five top executives for each company in the sample. As our perquisite measures are for 2006 we use ownership for 2005 to avoid any potential issues with possible joint determination of contemporaneously measured values for ownership and perquisite consumption ${ }^{6}$. Since prior literature is mixed regarding whether managerial ownership serves an overall positive or negative benefit we have no prediction concerning the relation between managerial ownership and perquisite consumption. We obtain ownership data from the Compustat ExecuComp database.

There is mounting evidence regarding the impact of institutional investors on corporate actions (see Hartzell and Starks, 2003; Gillan and Starks, 2007; Becht et al., 2009). Becht et al.

\footnotetext{
${ }^{5}$ Our board independence measure is the number of outside directors scaled by total board membership. Prior literature has shown that the ratio of independent board members mitigates the incidence of fraud, reduces the level of discretionary accruals and reduces the level of optimism in management forecasts (Beasley 1996, Dechow et al. 1996, Farber 2005, among others), however, find little evidence of this relation.

${ }^{6}$ Fahlenbrach and Stulz (2009) is one paper that uses a similar lagged approach. Fahlenbrach and Stulz (2009) examine the relation between managerial ownership and firm value. The paper uses the lagged value of managerial ownership and relates it to Tobin's Q, their measure of firm value in the next period. Managerial ownership is thus treated as exogenous. Similarly, we measure perquisite consumption one period after our dependent variable, managerial ownership thus seeking to minimize endogeneity.
} 
(2009), for instance, highlight the important behind-the-scenes influence of institutional investors and the positive value-related effects of such jawboning. If institutions bring pressure on managers to make efficient decisions, we would expect to observe an inverse relation between institutional ownership and perquisite consumption, if perquisite consumption stems from an agency problem. We measure institutional ownership as the percentage of shares held by institutional owners. ${ }^{7}$

Another internal governance mechanism that has received increased attention is the founder/founding family. The wealth of the founding family is tied up in the firm thus providing incentives to monitor management (Jensen and Meckling, 1976; Villalonga and Amit, 2006; Weisskopf, 2012). This research suggests that the presence of a founder/founding family should be a disciplining presence and serve a monitoring role because there is incentive alignment between the family and non-family shareholders. The flip side of this argument is the entrenchment effect, where we have founders extracting resources for their own benefit. Anderson et al. (2009) find evidence that in opaque environments founder/founding family firms have incentives to extract resources for their private benefit. Chen et al. (2012) similarly find more of an entrenchment effect in founder/founding family firms when internal controls are weak. These weak internal controls lead to more accounting misstatements and fraud than in non-family firms. The literature is mixed as to whether founder/founding firms incentives are aligned with shareholders or whether the entrenchment effect leads to resource extraction. We therefore do not have a prediction for this variable. We use the measure of founder/founding family ownership from Bagnoli et al. (2008) where the presence of the founder or descendants in management, on the board or among the company's top shareholders is an indicator variable set equal to 1 and 0 otherwise.

\footnotetext{
${ }^{7}$ Prior studies that examine the monitoring role of institutional investors on corporate decision making and financial reporting include, Bange and DeBondt (1998), Bushee (1998), Chung et al. (2002) and Ajinkya et al. (2005).
} 
Numerous authors including Hart (1983), Hermalin (1992), Schmidt (1997) and Karuna (2007), Giroud and Mueller (2010), suggest that product market competition can act as an important disciplining force by driving out bad managerial practices. Karuna (2007) shows that several measures of product market competition influence management incentives. Karuna (2007) uses price-cost margin (Demsetz, 1997) an indicator of product substitutability. More intense competition is predicted to produce a smaller price-cost margin. We follow Karuna (2007) and calculate the price-cost margin as sales less operating costs divided by operating costs, all at the four-digit SIC code level. We expect a negative relation to exist between product substitutability and the amount and level of perquisites if perquisites are consumed as a consequence of an agency problem. The second dimension of competition, market size reflects the demand in a particular industry. If demand is high, less competition may be present and less discipline. We would thus expect a positive relation between market size (measured by industry sales at the four-digit SIC code level) and the amount and number of perquisites. The last dimension of competition is entry costs, which represent the minimal level of investment that must be incurred by new entrants into the industry. If entry costs are high this deters new firms from entering the market. The firms who are currently operating in the market then enjoy lower competition due to the barrier to entry. We thus expect a positive relation between entry costs (measured by the average of property, plant and equipment by the four-digit SIC code level then weighted by each firm's market share in this industry and the amount) and level of perquisites.

\section{Presence of Potential Agency Problems}

Jensen (1986) suggests that when managers have access to excess free cash flow, they may tend to spend it in ways that benefit themselves but which reduce shareholder wealth. One way in which managers may waste cash flow is through the consumption of extra perquisites. Jensen 
(1986) argues that companies characterized by few growth opportunities but high cash flow present prime settings for the abuse of resources by managers. We define the variable GRW as 1 for firms that have low growth opportunities but high cash flows, and 0 otherwise. Using the universe of the Compustat 2006 research file, we calculate the Fama-French (1997) industry adjusted sales growth and free cash flow values for each firm. We then use the median values of industry-adjusted growth and free cash flow to assign a value to GRW for each firm. If perquisite consumption is evidence of managerial excess and Jensen's hypothesis is valid then we predict that perquisite consumption and GRW should be positively related, ceteris paribus.

Several academic studies provide evidence of the destructive effect that corporate diversification has on firm value (for example, Comment and Jarrell, 1995; Liebeskind and Opler, 1995; Lang and Stulz, 1994; Servaes, 1996; among others). Denis et al. (1997), Jiraporn et al. (2006) and Hoechle et al. (2012) present evidence suggesting that the diversification discount is inversely related to corporate governance quality. Company-level diversification has been associated with the hypothesis that company-level decisions may be motivated by managerial interests that are not in line with those of shareholders, which suggests the number of business segments may be an indicator of agency problems within the firm. We would expect to see a positive relation between the number of business segments and perquisite consumption, if perquisite consumption is the product of an agency conflict.

Shareholders of modern corporations delegate most expenditure decisions to managers. Companies whose capital is relatively less tangible (i.e., more growth options) may be subject to greater information asymmetry and agency problems as capital providers cannot observe, monitor, and assess spending on and the management of intangibles as easily as tangible assets (see for instance Smith and Watts, 1992; Gaver and Gaver, 1993, 1995; among others). If the relative 
contribution of intangibles to the total real capital of firms is correlated with the general presence of agency problems, then we would expect such a measure to be positively related to perquisite consumption. One measure of the relative contribution of intangible assets (e.g., growth opportunities) to a firm's total real capital is book-to-market ratio (BTM).We compute the BTM as the book value of total equity divided by the total market value of equity, and labeled as BTM and is measured at year-end 2005.

\section{Alternative Explanations to Perquisite Consumption}

\section{Compensation Policy}

Fama (1980) suggests that perks may serve to supplement an imperfect compensation policy. Executives may compensate to balance this perceived shortfall in cash compensation by consuming perquisites. In this context, perquisites are not necessarily detrimental to value but act to complete managerial compensation programs. This theory predicts a negative relation between abnormal compensation and the level of perquisites. We follow Yermack (2006) and measure abnormal compensation as the residual value from the regression of the sum of CEO's nonperquisite compensation (salary, bonus and option awards) on the log of firm sales, CEO tenure, size adjusted stock returns and industry effects captured by two digit SIC dummy variables. ${ }^{8}$ We label the variable, Abnormal comp.

\section{Managerial Productivity}

Rajan and Wulf (2006) argue that the firm may benefit by offering perquisites because they are a strategic factor useful in maximizing the productivity of management, and hence are by design part of an optimal compensation policy. The premise is that some perks could enhance the

\footnotetext{
${ }^{8}$ Our estimation is based on the universe of 2006 ExecuComp database.
} 
use of an executive's time thereby enhancing productivity. One possible implication of this argument is that more productive executives will receive more perks.

This is similar to the views of Holmstrom (1979) and Smith and Watts (1992) which suggest that higher marginal product decision makers are rewarded with higher compensation. Under this explanation, we would expect to observe that more productive firms pay greater perquisites and a positive association between productivity and perquisite consumption. We measure corporate productivity using a measure developed by Demerjian et al. (2012). The measure assigns an efficiency score to a firm based on inputs (capital and expenses) and outputs (revenue) for the company after accounting for industry effects. ${ }^{9}$ We label the variable Efficiency. $\underline{\text { Firm Size }}$

Large firms may seek to attract high marginal product managers since such firms have greater resources to manage. If perquisites are a reward for productivity then we would expect large firms to provide greater rewards to a high marginal product manager as compared to a low marginal product manager. As a consequence if paying greater perquisites allows such firms to attract better managers with a higher marginal productivity, we would expect a positive relation between a measure of firm size and perquisite consumption.

\section{$\underline{\text { Taxes }}$}

Disclosure of total compensation provides the IRS with another tool to monitor whether information on a company's tax return is accurate. ${ }^{10}$ If disclosure of a perquisite amount is incomplete, as was the case prior to 2006, firms might view perquisite awards as a tax-advantaged way to pay their executives (Rajan and Wulf 2006). Another possibility of course follows from

\footnotetext{
${ }^{9}$ We thank Peter Demerjian and Sarah McVay for providing us the efficiency score data used in this study.

${ }^{10}$ McGahran (1988) provides evidence that the SEC's disclosure requirements may benefit the Internal Revenue Service (IRS).
} 
the fact that many perquisites are not taxable income to the executive receiving them. If the marginal tax rate of the executive is positive then the executive will prefer a non-taxable perquisite to receiving the same amount as taxable income, ceteris paribus.

As we are examining a cross-section of firms for the same year, the statutory federal tax rate is the same for all executives however the state tax rates they face will vary depending upon their state of residence. We define the variable state tax as the highest marginal state personal income tax rate for the state in which a company is headquartered. We predict that the higher the marginal tax rate in the state in which a company's headquarters resides, the more executives will prefer perks. The simple reason is tax avoidance since perquisites are not taxable income to the executives.

\section{$\underline{\text { Managerial Status }}$}

Frank (1985) argues that individuals are concerned with the social position of the groups to which they belong, and also with their positions within those groups. Rajan and Wulf (2006) argue that to the extent relative status within the firm increases an executive's utility, and to the extent that perquisite levels are positively associated with status, providing perquisites may be a cost-effective way of compensating executives. Simply, the marginal cost to the company of a perquisite award may be less than the marginal cost if the award was made as salary. This would occur if the executive values the marginal perquisite award more highly due to the status it bestows in the eyes of his or her peers.

Further, Frank (1985) and Ranjan and Wulf (2006) suggest that managerial consumption of perquisites is regarded as a measure of status by executives, similar to other potential status proxies such as the size and complexity of the company. If status dictates the demand for perquisites by executives, then at one level perquisite consumption for status purposes is just 
another manifestation of the presence of an agency problem. Rajan and Wulf (2006) predict that large firms are probably more likely to fall into this category. We employ as a measure of size to capture this effect the total market capitalization of the firm, computed using data from CRSP measured at year end, prior to the release of the proxy statement. We use a log transform of market capitalization in our analyses.

\section{Data and Descriptive Statistics}

\section{Perquisite Disclosure}

Prior to August 2006 the reporting of perquisite awards by U.S. corporations was limited because of the SEC disclosure requirements then in effect. The SEC proposed a new set of disclosure rules in early 2006 which became final on August 29, 2006 and applied to proxy statements filed with the SEC on or after December 15, 2006 (SEC Release 33-8732A). ${ }^{11}$ Under the new rules, if the aggregate perquisite award exceeds $\$ 10,000$, the perquisite must be identified and disclosed. In addition, if the value of a perquisite is the greater of $\$ 25,000$ or $10 \%$ of total perquisites, its value must be disclosed. ${ }^{12}$

By the new SEC rules, an item is not a perquisite "if it is integrally and directly related to the performance of the executive's duties" (SEC Release 33-8732A), but an item is a perquisite "if it confers a direct or indirect benefit that has a personal aspect, without regard to whether it

\footnotetext{
${ }^{11}$ Executive Compensation and Related Party Disclosure, SEC Release 33-8732A (August 29, 2006).

${ }^{12}$ Prior to the new SEC rules, the SEC required firms to disclose in their proxy statements any perks over $\$ 50,000$ or $10 \%$ of total cash compensation and to identify specifics if each perquisite was $25 \%$ of total perquisites value in proxy statements (SEC Release No. 33-6962. see SEC 1992). These thresholds potentially allowed firms to avoid disclosure through a policy of strategically allocating just less than the thresholds. The new rules establish a minimum threshold amount for reporting perquisites of $\$ 10,000$. Once reported, each perquisite and its amount have to be identified in subsequent years' proxy statements if the value is more than $\$ 25,000$ or $10 \%$ of the total perquisites.
} 
may be provided for some business reason or for the convenience of the company" and "unless it is generally available on a non-discriminatory basis to all employees." (SEC Release 33-8732A). ${ }^{13}$

\section{The Perquisite Data}

Our initial sample is comprised of all firms included in the S\&P 1,500 as of the end of 2006 which also have governance data available in the RiskMetrics Group’s (ISS Governance Services) database of corporate governance indicators for the year 2005. ${ }^{14}$ We require that each sample firm have accounting data (Compustat) and stock price data (CRSP) available for the year ended 2005. We excluded firms from the financial sector (SIC codes 6000-6999). The process of applying these screens to companies which issued proxy statements between December 15, 2006 and June 30, 2007 produced a sample of 693 companies. We focus on the time period immediately after the rule change in an effort to obtain a true picture of perquisite consumption before firms decided to eliminate or restructure their perquisite programs. Our narrow window was an attempt to mitigate sample loss due to changes in perquisite programs. Even with this narrow window, approximately three percent of our sample firms decided to change their perquisite programs. Extending the window would have allowed firms more time to react to the rule change and ultimately restructure or eliminate perquisite programs.

We collected compensation and perquisite consumption information for the CEO and the five top executives for whom the reporting rules required perquisite data disclosure. Details on

\footnotetext{
${ }^{13}$ The SEC provides the following items as examples of perquisites: "club memberships not used exclusively for business entertainment purposes, personal financial or tax advice, personal travel using vehicles owned or leased by the company, personal travel otherwise financed by the company, personal use of other property owned or leased by the company, housing and other living expenses (including but not limited to relocation assistance and payments for the executive or director to stay at his or her personal residence), security provided at a personal residence or during personal travel, commuting expenses (whether or not for the company's convenience or benefit), and discounts on the company's products or services not generally available to employees on a non-discriminatory basis.”

${ }^{14}$ RiskMetrics Group purchased the data compilation arm of IRRC in 2006. The arm of RiskMetrics Group which compiles the current data is ISS Governance Services. We accessed the data via the WRDS portal.
} 
perquisite awards are reported in a footnote to the compensation summary table of the proxy statement and include the number of different awards, the sizes of the awards, and how the awards are distributed. We also require that all salary information for the five top executives be reported and that all sample firms comply with the new SEC disclosure rules in preparing their compensation summary tables. This reduced the sample to 645. Thirty-seven companies are excluded for lack of data. There are 608 firms in our final sample. Based upon the Fama-French (1997) industry classifications our sample covers forty-three different industries. Utilities have the highest percentage representation in our sample (67 firms, $11.02 \%$ ) while the remainder (not reported) are fairly evenly distributed across the industry groups. ${ }^{15}$

\section{Descriptive Statistics for Perquisites}

We classify perquisite items into 10 broad categories: ${ }^{16}(1)$ air and long distance travel expenses, (2) company car and local transportation, (3) entertainment and other extra-curricular activities, (4) personal and family related perquisites that enhance the home/family situation of the executive, (5) severance package and/or special dividend distribution, (6) legal, financial, and tax services, (7) medical allowances and medical expenses paid by the corporation, (8) financial perquisites unrelated to savings or retirement, (9) administrative privileges, and (10) other. Firms sometimes disclose the use of a perquisite item but not the exact dollar amount of the perquisite. Our sample includes 10 such companies. In such cases we record the perquisite only as having

\footnotetext{
${ }^{15}$ The tabulation is available from the authors upon request.

${ }^{16}$ In classifying perquisite items, we exclude non-perquisite items that are included in "All Other Compensation" such as (1) severance/retirement/change-in-control payments, (2) dollar value of life insurance premiums, (3) discounted security purchases (unless generally available), and (4) dollar value of dividends or other earnings paid on stock/options when not factored into the grant date fair value. However, we view tax-gross ups as perquisites and include them in our analysis. The use of "All Other Compensation" as an indicator of total perquisite consumption will overstate the dollar value of perquisites.
} 
been paid. Appendix A provides a detailed description of our classification scheme and each perquisite category's sub-components.

Table I presents the frequency of use of each perquisite by executive type: CEO, CFO, and the next three most highly compensated executives. We label the latter executives, EA, EB and EC. Approximately $88 \%$ of the top five executives receive at least one perquisite item and there is no statistical difference. The most frequent perquisite, which was provided by over $50 \%$ of the sample firms, was the provision for legal, financial and tax services (Type 6). In addition to the payment for the preparation of tax returns, this category includes tax gross-ups. The second most frequent type of perquisite, provided by roughly $40 \%$ of the sample firms, was the provision of a company car and /or local transportation (Type 2). This category includes payments for leased automobiles, chauffeured automobiles, gasoline and parking. The third and fourth most frequent types of perquisites, provided by roughly 33\% of the sample firms each, were the provision for air and long distance travel expenses (Type 1) and personal and family-related perquisites (Type 4). Type 1 perquisites include access to a corporate jet, travel on commercial airlines, lodging and travel allowances. The least frequent types of perquisite awards were for medical and health benefits and administrative privileges, both provided by less than $7 \%$ of the firms in our sample.

Table II reports individual components of compensation, by executive type. The median value of CEO salary is $\$ 780,000$, which is twice that of the other four top executives. This pattern is observed across the other components of compensation as well. The median values of the other compensation components for the CEO including, stock awards, options and non-equity compensation, are as much individually as the baseline salary. The median dollar value for perquisites is $\$ 47,467$ for the CEO, which is approximately $6 \%$ of the CEOs' median base line salary. Similar to the other compensation components, the median dollar value for the perquisites 
of the other top executives drops to $\$ 14,253, \$ 18,000, \$ 15,451$ and $\$ 13,850$ respectively, representing about $4 \%$ of their median base line salaries. Although $6 \%$ is a minuscule amount of the CEO's salary, if this amount is due to agency problems, then the amount of the expropriation becomes a secondary concern and the material issue is the loss of shareholder wealth.

We examine three alternative but complimentary measures of perquisite consumption: 1) the dollar value of perquisites, 2) the number of different perquisites, and 3) the types of perquisites. Each measure serves as an indicator of perquisite consumption. The use of three alternative measures allows us to test the robustness of our conclusions to both how perquisites are measured as well as the statistical models employed in our analyses. In addition to observations on the dollar levels of perquisites as highlighted in Table II, we also examine the number of perquisites consumed. Data on the number of perquisite awards are reported in Table III, Panel A. On average, CEOs receive 2.6 different types of perquisites. In total, the five top executives receive on average 12.95 perquisites per company.

\section{EMPIRICAL FINDINGS}

\section{Determinants of Perquisite Awards}

\section{$\underline{\text { Governance Related Variables }}$}

Table III reports the descriptive statistics of our explanatory variables. Throughout we employ lagged values of explanatory variables where appropriate to minimize any contemporaneous relations that might exist between those variables and/or measures of perquisite consumption. Panel B of Table III reports statistics on governance-related variables. We find the GIM index has a mean of roughly 9.5 and a median value of 9 . The large mean suggests weak stakeholder rights. We also find that the five top executives own (Mgmt own) approximately 2.12\% of the shares outstanding and the mean fraction of the board composed of independent directors 
(Board Indep) is 74\%. The sample firms are heavily owned by institutions. The mean percentage of shares held by institutions (Inst holdings) is approximately $77 \%$ while $27.1 \%$ of our sample is represented by founder/founder family firms (Family firm).

The next three variables are potential disciplining mechanisms that Karuna (2007) examined in relation to managerial incentives. We find the average price-cost margin (Price-cost $\mathrm{mrg}$ ) for the sample firms is 0.141 which is our measure of product substitutability. The higher the value of this measure the less substitutable the product. The logarithmic value of market size (Mkt size) has an average value of 10.59, which is consistent with that of Karuna (2007). Our measure of entry costs (Entry cost) has an average value of 3.85 which is significantly smaller than the mean of 7.0 captured by Karuna (2007) suggesting the entry costs in our sample firms are significantly lower.

\section{Variables Pertaining to Alternative Explanation to Perquisites}

Panel C of Table III reports statistics related to our alternative explanation and control variables. Jensen (1986) postulated that firms with both high cash flows and low growth (GRW) were apt to spend the cash in ways that didn't benefit shareholders. We find that $42 \%$ of our sample fits into this category. Fama (1980) postulated that if managers view their compensation as imperfect, they will reward themselves with additional compensation. Average abnormal compensation (Abnormalcomp), in our sample equals $-\$ 110,000$. Note that because we use the universe of the firms contained in the ExecuComp database when estimating this value, the median value for our sample is not zero. The variable, Efficiency was defined by Demerjian et al. (2012) to represent the relative ability of managers to transform inputs into outputs within a given FamaFrench (1998) industry. ${ }^{17}$ The range for this variable is 0 to 1 with zero representing the least

\footnotetext{
${ }^{17}$ See Demerjian, Lev and McVay (2012).
} 
efficient and 1 the most efficient. In our sample, Efficiency has a mean value of 0.73 suggesting that the managers in our sample firms are on average efficient in the management of company resources. Finally, we find that the marginal state tax rate (State tax) has a mean value of 5\% and the median value of the number of business segments in our sample is 3. Market value and the book-to-market ratio (BTM) have mean values of $\$ 10,954$ (million) and 0.42 respectively. ${ }^{18}$

Table IV reports the pair wise correlations between the continuous variables related to perquisite consumption and governance. The logarithmic values of the dollar amounts of perquisites consumed are positively correlated with GIM and generally statistically significant at conventional levels, consistent with the conjecture that weak governance is associated with greater perquisite consumption. Management ownership (Mgmt own) of shares is negatively correlated with perquisite consumption and generally statistically significant, consistent with higher ownership stakes dampening agency problems. Our measures of board independence (Board indep) and institutional holdings (Inst holdings) tend not to show a significant correlation with perquisite consumption. Two of the measures of real market competition tend to be significantly correlated with perquisite consumption and have the expected signs. Both greater market size (Mkt size) and entry costs (Entry cost) show a positive and statistically significant correlation.

\section{The Dollar Amount of Perquisites}

Panels A and B of Table V present model estimation results when the dependent variable is the dollar value of perquisites consumed by the CEO and the five top executives, respectively. Each of the models presented in Table $\mathrm{V}$ reports the association between our measures of corporate governance and perquisite consumption. In our models the proxy variables representing our alternative explanation are also included. The models are estimated by ordinary least squares

\footnotetext{
${ }^{18}$ We use the log transform of market capitalization as our measure of firm size.
} 
methods and robust standard errors are used in the computation of coefficient tests statistics (see Greene, 2008).

The results presented in Panel A of Table V indicate that GIM, Inst holdings, Mkt size and Entry cost are statistically significant and in the predicted directions. These results taken together suggest that when a firm has a weak governance structure perquisite consumption is higher. The results also show that perquisites may serve another role in the organization. Specifically, perquisites may be a reward for productive managers. In columns (1) through (3), Efficiency is positive and statistically significant suggesting that more efficient managers are rewarded with a higher dollar amount of perquisites. There appears to be a duality involved with perquisite consumption. In firms with weak governance mechanisms, perquisite awards are the result of agency problems, but in the presence of efficient managers the increase in perquisite awards represents a reward for managerial efficiency. We also find Numberofsegs is positive and significant which is problematic and suggests there is some support for the status argument.

Panel B of Table V presents the regression results for models using the dollar amount of perquisites provided to all five top executives. The results are similar to those in Panel A except Inst holdings is no longer significant. Overall, Panel Table V shows that weak governance and weak product market discipline are associated with higher levels of perquisite consumption. But in the face of an efficient manager perquisite consumption increases. Again, the results suggest a dual purpose for perquisite consumption within the organization.

In untabulated results, we divide our sample by size based on total assets. For small firms we find stronger results, governance reduces the level of perquisites to both the CEO and the five top executives. We then compare our current sample to the period before the rule change in an effort to investigate what impact the rule change had in the post period and find that in the post 
period, the coefficient on GIM shrinks significantly. This suggests that small firms benefitted most from the rule change. As a result of the change, smaller firms have a mechanism to control perquisite consumption that didn’t exist before.

\section{The Number of Perquisites}

Table VI reports results in which the dependent variable examined is the number of distinct perquisite items provided to the CEO (Panel A), and the five top executives (Panel B). The number of perquisite items has several merits as a dependent variable. First, the dollar measure may not correctly depict the proclivity of perquisite consumption. Due to the nature of the dependent variable (i.e. count data) we estimate the model using a Tobit regression with quasi-maximum likelihood methods (see Greene, 2008).

We find results that are similar to those presented in Table V. Panel A of Table VI presents results for the number of perquisite items awarded to the CEO. The coefficient on Efficiency is consistently positive and significant at conventional levels, indicating that efficient managers enjoy a greater number of perquisites. GIM is positively and significantly associated with the number of perquisite items. Mgmt own is negatively associated with the number of perquisites, albeit at slightly more elevated test levels. Similar to the results in Table V, Mkt size and Entry cost have a positive and statistically significant association with the number of perquisites. Overall, the results presented in Table VI are generally consistent with the results presented in Table V. One important exception between Tables V and VI is the evidence that managerial ownership has a negative influence on the number of perquisites consumed.

In summary, the number of perquisites awarded increases as overall governance quality weakens, as the threat of product market competition decreases, and if managers have a smaller 
ownership stake. However, the evidence also shows the duality of perquisites with them also serving as a reward for high marginal product managers.

\section{The Types of Perquisites Consumed}

In this section we examine the firm's choice to provide a perquisite of each type. We report results based upon CEO perquisite consumption only for brevity. A binary dependent variable is defined for each perquisite type. We estimate a probit specification for each perquisite type (Greene, 2008). ${ }^{19}$ Table VII provides the probit estimation results.

The results indicate that perquisites classified as Type (1), air \& long distance travel expenses (Panel A), Type (5), equity related perquisites not included in stock options or other equity compensation (Panel B), Type (6), legal, financial, and tax services (Panel C) and Type (8), financial perquisites unrelated to savings or retirement (Panel D), are more likely to be consumed by executives of firms characterized by weak governance. These panels indicate an association between GIM, institutional holdings (Inst holdings), management ownership (Mgmt own), market size (Mkt size) and entry costs (Entry cost) and the choices of these particular perquisites. The results suggest perquisite awards are indicative of an agency problem and are more prone to occur in situations where weak governance or weak external market pressures are present.

In summary, we examine three alternative but complimentary measures of perquisite consumption: 1) the dollar value of perquisites, 2) the number of different perquisites, and 3) the types of perquisites. Each measure serves as an indicator of perquisite consumption. Based on the results of our empirical analysis we find results that suggest firms with weak governance, which is a sign of agency problems, award more perquisites. We also find results that support the contention that perquisites are an award for managerial productivity. This suggests a dual role for

\footnotetext{
${ }^{19}$ For brevity we report results based upon CEO perquisite consumption only and show the perquisite types with significant results.
} 
perquisites. On one end of the spectrum, perquisite awards serve as a reward for productivity and on the other end they are a precursor to agency problems. We find no support for our free cash flow, abnormal compensation, intangible intensity or tax alternative explanations for perquisite consumption.

\section{CONCLUSIONS}

The issue of whether perquisite awards reflect an agency problem or are provided to reward high marginal product managers is an open question in the accounting literature. The studies of Yermack (2006) and Rajan and Wulf (2006) reach different conclusions on the matter. Collectively, the results from this study show a consistent pattern of results. The results indicate that weak internal governance quality, weak product market competition, low managerial ownership and institutional ownership are associated with perquisite consumption, whether measured in dollars or number of perquisites awarded. Larger more complex companies (companies with more business segments) also award more perquisites, consistent with the presence of agency problems, but these results are also consistent with large firms hiring and rewarding high marginal product managers. We also find evidence that firms characterized by greater managerial efficiency award greater perquisites, consistent with the hypotheses that perquisites enhance productivity. Hence we conclude that there is a duality associated with perquisite awards depending on the organization. As a result, neither the agency hypothesis of perquisites indicating managerial abuse of privilege, nor the hypothesis that perquisites are solely the product of reward for productivity can individually explain the data, rather both hypotheses taken together explain the seemingly disparate results in the literature.

A limitation of our study is our focus on the time period immediately after the rule change, firms that filed proxy statements between December 15, 2006 and June 30, 2007. This narrow 
window was chosen intentionally so firms did not have time to react to the rule change by restructuring or eliminating their perquisite programs. The narrow focus, however, limits the generalizability of our results to time periods beyond our sample period. This limitation, however, opens the door for an interesting question we leave for future research which is what factors drive the choice by firms to change their policies related to perquisites and the subsequent, valuation consequences of such changes, all of which must be predicated on a model of expectations. Roughly three percent of the firms in our sample decided to change their perquisite program, following institution of the new SEC reporting rule. Unfortunately, the sample of changes is far too small for us at this time to make meaningful statements about the factors driving these choices, we do observe a pattern of negative revaluations (not reported) for these cases and that firms with high CEO compensation prior to the institution of the new SEC rules did tend to change policies. 


\section{References}

Anderson, R., Duru, A., Reeb, D. (2009), “Founders, heirs and corporate opacity in the United States.” Journal of Financial Economics 92, 205-222.

Ajinkya, B., Bhojraj, S., Sengupta, P. (2005), “The governance effect of institutional investors and outsider directors on the properties of management earnings forecasts." Journal of Accounting Research 43, 343-376.

Bange, M., DeBondt, W. (1998), “R\&D budgets and corporate earnings targets.” Journal of Corporate Finance 4, 153-184.

Bagnoli, M., Liu, H., Watts, S., (2008), "Family firms, debtholder shareholder agency costs and the use of covenants in private debt.” Working Paper, Purdue University.

Beasley, M. (1996), "An empirical analysis of the relation between the board of director composition and financial statement fraud.” The Accounting Review 71, 443-465.

Becht, M., Bolton, P., Roell, A. (2003), “Corporate governance and control.” Handbook of the Economics of Finance, Vol. 1A, eds. Constantinides, G., Harris, M., Stulz, R. North-Holland, 4-109.

Becht, M., Franks, J., Mayer, C., Rossi, S. (2009), "Returns to Shareholder Activism: Evidence from a Clinical Study of the Hermes U.K. Focus Fund." Review of Financial Studies 22, 4009-4056.

Berger, P., Ofek, E. (1995), “Diversification's Effect on Firm Value.” Journal of Financial Economics 37, 39-65.

Bhagat, S., Bolton, B. (2008), “Corporate governance and firm performance.” Journal of Corporate Finance 14, 257-273.

Bushee, B. (1998), “The influence of institutional investors on myopic R\&D investment behavior.” The Accounting Review 73, 305-333.

Chen, X., Feng, M., Li, C. (2012), "Internal control in family firms: characteristics and consequences.” Working Paper, University of Pittsburgh.

Chung, R., Firth, M. and Kim, J. (2002), “Institutional monitoring and opportunistic earnings management.” Journal of Corporate Finance 8, 29-48.

Comment, R., Jarrell, G. (1995), “Corporate focus and stock returns.” Journal of Financial Economics 37, 67-87.

Core, J., Guay, W., Larcker, D. (2003), “Executive equity compensation and incentives: A survey.” Economic Policy Review 9, 27-50.

Dechow, P., Sloan, R. and Sweeney, A. (1996), "Causes and consequences of earnings manipulation: an analysis of firms subject to enforcement actions by the SEC." Contemporary Accounting Research 13, 1-36.

Demerjian, P., Lev, B. and McVay, S. (2012), "Quantifying Managerial Ability: A New Measure and Validity Tests.” Management Science 58, 1229-1248. 
Demsetz, H. (1997), “The economics of the firm: Seven critical commentaries.” Cambridge University Press, Cambridge, MA.

Denis, D., Denis, D., Sarin, A. (1997), “Agency problems, equity ownership, and corporate diversification.” Journal of Finance 52, 135-160.

Denis, D., Denis, D., Yost, K. (2002), “Global diversification, industrial diversification, and firm value.” Journal of Finance 57, 1951-1979.

Djankov, S., La Porta, R., Lopez-de-Silanes, R., Shleifer, A. (2008), “The law and economics of self-dealing.” Journal of Financial Economics 88, 430-465.

Fahlenbrach, R., Stulz, R. (2009), “Mangerial ownership dynamics and firm value.” Journal of Financial Economics 92, 342-361.

Fama, E. (1980), “Agency problems and the theory of the firm.” Journal of Political Economy 88, 288-307.

Fama, E., French, K. (1997), “Industry costs of equity.” Journal of Financial Economics 43, 153193.

Fama, E., Jensen, M. (1983), “Separation of ownership and control.” Journal of Law and Economics 26, 301-325.

Farber, D. (2005), "Restoring trust after fraud: Does corporate governance matter?” The Accounting Review 80, 539-561.

Frank, R. (1985), “The demand for unobservable and other nonpositional goods." American Economic Review 75, 101-116.

Gaver, J., Gaver, K. (1993), “Additional evidence on the association between the investment opportunity set and corporate financing, dividend, and compensation policies.” Journal of Accounting and Economics 16, 125-160.

Gaver, J., Gaver, K. (1995), “Compensation policy and the investment opportunity set.” Financial Management 24, 19-32.

Gillan, S., (2006), “Recent Developments in Corporate Governance: An Overview.” Journal of Corporate Finance 12, 381-402.

Gillan, S., Starks, L. (2007), “The evolution of shareholder activism in the United States.” Journal of Applied Corporate Finance 19, 55-73.

Giroud, X., Mueller, H. (2010), “Does corporate governance matter in competitive industries?” Journal of Financial Economics 95, 312-331.

Gompers, P., Ishii, J., Metrick, A. (2003), “Corporate governance and equity prices.” Quarterly Journal of Economics 118, 107-155.

Greene, W. (2008), Econometric Analysis, $6^{\text {th }}$ ed. Pearson-Prentice Hall, Upper Saddle River, NJ.

Hart, O. 1983, “The market mechanism as an incentive scheme.” Bell Journal of Economics 13, 366-382.

Hartzell, J., Starks, L. (2003), “Institutional Investors and Executive Compensation.” The Journal of Finance 58, 2351-2374. 
Healy, B. 2013, “Executive perks still alive and well.” Boston Globe, 12 April.

Hermalin, B. (2005), “Trends in corporate governance.” Journal of Finance 60, 2351-2384.

Hermalin, B. (1992), “The effects of competition on executive behavior." Rand Journal of Economics 23, 350-365.

Hoechle, D., Schmid, M., Walter, I., Yermack, D. (2012), "How much of the diversification discount can be explained by poor corporate governance?” Journal of Financial Economics 103, 41-60.

Holmstrom, B. (1979), “Moral hazard and observability.” Bell Journal of Economics 10, 74-91.

Holmstrom, B., Kaplan, S. (2001), "Corporate governance and takeovers in the U.S.: Making sense of the '80s and '90s.” Journal of Economic Perspectives, 121-144.

Holmstrom, B., Kaplan, S. (2003), “The state of U.S. corporate governance: What's right and what's wrong?” Journal of Applied Corporate Finance 15, 8-20.

Jensen, M. (1986), “Agency costs of free cash flows, corporate finance and takeovers.” American Economic Review 76, 323-329.

Jensen, M., Meckling, W. (1976), “Theory of the firm: Managerial behavior, agency costs and ownership structure.” Journal of Financial Economics 3, 305-360.

Jiraporn, P., Kim, Y., Davidson, W., Singh, M. (2006), “Corporate governance, shareholder rights, and firm diversification: An empirical analysis.” Journal of Banking and Finance 30, 947963.

Karuna, C. (2007), “Industry product market competition and managerial incentives.” Journal of Accounting and Economics 43, 275-297.

Lang, L., Stulz, R. (1994), “Tobin’s q, corporate diversification, and firm performance.” Journal of Political Economy 102, 1248-1280.

Liebeskind, J., Opler, T. (1995), “The causes of corporate refocusing: Evidence from the 1980s.” Working paper, University of Southern California.

McConnell, J., Servaes, H. (1990), “Additional evidence on equity ownership and corporate value.” Journal of Financial Economics 27, 595-612.

McGahran, K. (1988), “SEC disclosure regulation and management perquisites.” The Accounting Review 63, 23-41.

Morck, R., Shleifer, A., Vishny, R. (1988), "Management Ownership and market valuation: An Empirical Analysis.” Journal of Financial Economics 20: 293-315.

Murphy, K. (2002), "Explaining executive compensation: Managerial power versus the perceived cost of stock options.” University of Chicago Law Review 69, 847-857.

Murphy, K. J. (1999), “Executive compensation.” In Orley Ashenfelter and David Card (eds.), Handbook of Labor Economics, Elsevier, North Holland.

Rajan, R., Wulf, J. (2006), “Are perks purely managerial excess?” Journal of Financial Economics 79, 1 -33. 
Ross, S. (1973), “The economic theory of agency: The principal's problem.” American Economic Review 62, 134-139.

Schmidt, K. (1997), "Managerial incentives and product market competition." Review of Economic Studies 64, 191-213.

Servaes, H. (1996), “The value of diversification during the conglomerate merger wave.” Journal of Finance 51, 1201-1225.

Shleifer, A., Vishny, R. (1997), “A Survey of Corporate Governance.” Journal of Finance 52, 737-83.

Smith, C., Watts, R. (1992), "The investment opportunity set and corporate financing, dividend, and compensation policies.” Journal of Financial Economics 32, 263-292.

Villalonga, B., Amit, R. (2006), "How do family ownership, control and management affect firm value.” Journal of Financial Economics 80, 385-417.

Weisskopf, J., (2012), “Executive Compensation in Family Firms: Fat Cats or Benefactors.” Working paper, University of Fribourg.

Yermack, D. (2006), "Flights of fancy: Corporate jets, CEO perquisites, and inferior shareholder returns.” Journal of Financial Economics 80, 211-242. 


\section{Appendix A: Perquisite classifications}

\begin{tabular}{|c|c|c|}
\hline Type & Description & Items Included \\
\hline 1 & $\begin{array}{l}\text { Air \& Long Distance } \\
\text { Travel Expenses - } \\
\text { Includes all air travel } \\
\text { expenses and other long- } \\
\text { distance travel expenses. }\end{array}$ & $\begin{array}{l}\text { - Personal use company aircraft - Expenses from the use of a company owned } \\
\text { or leased aircraft by an executive or the family/friends of the executive. } \\
\text { - Air travel allowance - Any expenses from air travel that are not the result of } \\
\text { the executive using a company owned or leased aircraft. This would include } \\
\text { such items as commercial airplane tickets. } \\
\text { - Other long-distance travel - This includes all of the costs associated with } \\
\text { executive long distance travel-hotels and lodging away from home as well } \\
\text { as the expenses associated with spouse and family accompanying the } \\
\text { executive. }\end{array}$ \\
\hline 2 & $\begin{array}{l}\text { Company car \& local } \\
\text { transportation - } \\
\text { Includes expenses } \\
\text { associated with car and } \\
\text { local transportation. } \\
\end{array}$ & $\begin{array}{l}\text { - Transportation allowance - This includes automobile insurance paid by the } \\
\text { company, as well as gas and parking. } \\
\text { - Use of company automobile - This category includes the personal use of a } \\
\text { company owned or leased automobile by the executive. }\end{array}$ \\
\hline 3 & $\begin{array}{l}\text { Entertainment and } \\
\text { other extra-curricular } \\
\text { activities - Includes all } \\
\text { entertainment and extra- } \\
\text { curricular activity } \\
\text { expenses, including } \\
\text { country club and dining } \\
\text { privileges. }\end{array}$ & $\begin{array}{l}\text { - Payments to clubs for membership dues, fees, and initiation -- Includes } \\
\text { health, lunch country and airway clubs. This category also includes alcohol, } \\
\text { meal discounts and allowances at nice restaurants. } \\
\text { - Vacation expenses and vacation payouts - This includes payments for } \\
\text { executive vacation and retreats. Entails items such as travel vouchers. } \\
\text { Payouts for vacations not used by executives also fall under this category, as } \\
\text { does holiday pay. } \\
\text { - Sporting and other entertainment events and expenses related to those events } \\
\text { - This would include the cost of tickets. }\end{array}$ \\
\hline 4 & $\begin{array}{l}\text { Personal and Family } \\
\text { Related Perquisites } \\
\text { that enhance } \\
\text { home/family situation } \\
\text { of the executive }\end{array}$ & $\begin{array}{l}\text { - Security - This entails personal and home security paid for by the } \\
\text { corporation for the executive. } \\
\text { - Housing allowances - This category encompasses all payments made by the } \\
\text { corporation for housing, whether it be temporary or permanent, and any } \\
\text { payments for home maintenance, home improvement, or utilities. } \\
\text { - Moving and Relocation - This category is for compensation to executives } \\
\text { for moving, relocating. This includes payments to previous employers for } \\
\text { moving to the company, foreign service premiums, and any expatriate } \\
\text { payments. } \\
\text { - Education expenses paid for by the corporation - This includes all education } \\
\text { expenses for the executive and the family. This would entail items like } \\
\text { college tuition and an "education allowance". }\end{array}$ \\
\hline 5 & $\begin{array}{c}\text { Equity related } \\
\text { perquisites not included } \\
\text { in stock options or other } \\
\text { equity compensation } \\
\end{array}$ & $\begin{array}{l}\text { - Encompasses any dividends and stock distributed to the executive, as well } \\
\text { as any special plans for the executive to purchase stock. }\end{array}$ \\
\hline 6 & $\begin{array}{l}\text { Legal, Financial, and } \\
\text { Tax Services }\end{array}$ & $\begin{array}{l}\text { - Legal fees - Any payments made by the corporation for legal fees or services } \\
\text { incurred by the executive. } \\
\text { - Financial and tax planning services - Corporation payments for financial } \\
\text { and tax planning services. } \\
\text { - Tax payments \& tax gross-ups - This category includes all tax payments and } \\
\text { gross-ups for the executive, with no attention given to the item being grossed } \\
\text { up. Designed to measure the amount of taxes paid by the corporation for the } \\
\text { executive. }\end{array}$ \\
\hline
\end{tabular}




\section{Appendix A: Perquisite classifications (continued)}

\begin{tabular}{|c|c|c|}
\hline 7 & $\begin{array}{l}\text { Medical and Health } \\
\text { Benefits }\end{array}$ & $\begin{array}{l}\text { - Medical allowances and medical expenses paid by the corporation - This } \\
\text { category includes any specific medical items such as: physicals for the } \\
\text { executive and family, dental and vision, prescription drugs, medical } \\
\text { reimbursements, physical training/therapy, and medical exams. }\end{array}$ \\
\hline 8 & $\begin{array}{l}\text { Financial Perquisites } \\
\text { unrelated to savings or } \\
\text { retirement }\end{array}$ & $\begin{array}{l}\text { - Imputed Interest } \\
\text { - Loans, Gifts, and Discounts - This category encompasses loans to the } \\
\text { executive, any interest payments made by the corporation on behalf of the } \\
\text { executive, any loans forgiven, any gifts to the executive, any discounts } \\
\text { granted to the executive. } \\
\text { - Executive allowances / Executive choice plans / Flexible spending plans / } \\
\text { cash allowances - This is a broad category meant to capture any allowances } \\
\text { allocated to executives that isn't specifically defined and gives the executive } \\
\text { discretion on how to use the money. } \\
\text { - Charitable and gift matching contributions - Contributions matched by the } \\
\text { corporation for donations and gifts given by the executive to a charity or } \\
\text { another entity. }\end{array}$ \\
\hline 9 & $\begin{array}{l}\text { Administrative } \\
\text { Privileges }\end{array}$ & $\begin{array}{l}\text { - Use of secretarial/administrative assistance and other support staff - This } \\
\text { would include using the services of a secretary for personal matters and } \\
\text { personal IT support. } \\
\text { - Corporation payments for supplies and equipment utilized by an executive. } \\
\text { Allowances given to the executive or reimbursement for payment of business } \\
\text { related expenses or services performed by the executive for the company. } \\
\text { This category includes director's fees. } \\
\text { - Communication expenses - Payments by the corporation for the executive's } \\
\text { cell phone service, internet service, and other communication related } \\
\text { services and expenses. } \\
\text { - Use of the company facilities / assets for personal use. Could include such } \\
\text { items like using the company's health facilities, or using a company boat. }\end{array}$ \\
\hline 10 & Other & - Used for items in which no distinct categorization could be readily identified. \\
\hline
\end{tabular}

